\title{
DETERMINING THE LOCATIONS OF POTENTIAL FIREFIGHTING TEAMS BY USING GIS TECHNIQUES
}

\author{
A. E. Akay ${ }^{1, *}$, İ. R. Karaş ${ }^{2}$, İ. Kahraman ${ }^{2}$ \\ ${ }^{1}$ Bursa Technical University, Faculty of Forestry, 16310 Bursa, Turkey - abdullah.akay@ btu.edu.tr \\ ${ }^{2}$ Karabük University, Faculty of Engineering, 78050 Karabük, Turkey - \{ismail.karas, idriskahraman $\} @$ karabuk.edu.tr
}

KEY WORDS: Disaster Management, Forest Fires, Firefighting Teams, GIS, Network Analysis, Shortest-path

\begin{abstract}
:
Wild forest fires are one of the most important disasters that affect the forest ecosystem especially in the regions with arid climate conditions. Besides, forest fires threats human life and results in seriously property loss. In order to fight forest fires effectively, it is crucial that firefighting team should reach fire location and start fire extinguishing activities within the critical response time. Since firefighting teams are transported to fire locations by fire-trucks, the optimum route with minimum travel time should be determined by considering available road network. "New Service Area" tool under "Network Analyst" extension of ArcGIS can be used to determine a region that can be reached from a point within a specified time period. In this study, it was aimed to evaluate the locations of current firefighting teams and investigate locations of potential firefighting teams using "New Service Area" tool. The study area is located in Mustafakemalpaşa in Bursa where forest lands are sensitive to forest fires at the second degree and there is currently one firefighting team in the area. The results indicated that $31.28 \%$ of forest land can be reached by current firefighting team within the critical response time. When including new firefighting teams, it was found that accessible forest lands increased to $71.55 \%$. It can be concluded that locating new firefighting teams should be established in the study area to increase the accessible forested areas on time and GIS-based decision support systems can be effectively used to fight forest fires regarding with disaster management.
\end{abstract}

\section{INTRODUCTION}

\subsection{General Instructions}

Forest fires caused by natural processes and human factors are seen as one of the most important factors affecting forest ecosystems (Akay et al., 2011). The climate changes and drought events increase air temperatures, reduce the humidity of the air, decrease the moisture of the flammable material, which increases the fire risk. Annually, thousands of hectares of forests are affected by forest fires, causing serious losses in terms of economic, ecological, and social point of views (Karabulut et al., 2013). Thus, forest fires adversely affect the sustainability of forest resources and cause biological and ecological effects on forest vegetation (Bilici, 2009).

Mediterranean ecosystems are highly sensitive to forest fires due to the composition of plant species and dry climate. Average of 4.000.000 hectares of forest land in the world and 550.000 hectares of forest land in Mediterranean basin are damaged by forest fires. In the Mediterranean countries between 2003 and 2012, 6\% of the forests in Greece, 5.6\% of the forests in Italy, $4.2 \%$ of the forests in Spain, $1.2 \%$ of the forests in France, and $0.4 \%$ of the forests in Turkey were damaged by forest fires (Eker and Abdurrahmanoğlu, 2018.

In Turkey, 12 million hectares of forest lands in the coastal band extending from the Mediterranean to Aegean coasts are "sensitive" to forest fires. Approximately 1250 forest fires occur annually and approximately 21.000 ha of forest lands are damaged (GDF, 2013). It is important for the firefighting teams to be deployed in the right locations in order to reach the fires as soon as possible by using the shortest and safest route (Akay et al., 2011; Akay and Sakar, 2009; Varol et al., 2010).
Especially in the areas sensitive to the fire, firefighting team must arrive to the scene in critical response time when the probability of controlling forest fires rises significantly (Keramitsoglou et al., 2004). Therefore, it is important to determine the areas that can be reached by firefighting team in critical response time. The critical response time are computed based on fire sensitivity level of the forested areas (Table 1). Fire sensitivity level is determined based on number of fire incidents and burned areas per year. As the number of fires and amount of burned areas increase fire sensitivity level increases from first degree to fifth degree (Kucuk and Unal, 2005).

\begin{tabular}{|l|c|c|c|c|c|}
\hline \multirow{2}{*}{} & \multicolumn{5}{|c|}{ Fire Sensitivity Degrees } \\
\cline { 2 - 6 } & I & II & III & IV & V \\
\hline Critical Response Time & 20 & 30 & 40 & 50 & 50 \\
\hline
\end{tabular}

Table 1. Critical response time (min) (Akay et al., 2012)

A GIS tools can be used to determine efficiency of fire trucks in responding forest fires (Dimopoulou and Giannikos, 2004). The vehicle travel speed on different road types with various design speed is critical to reach fires areas in the critical response time. Bonazountas et al. (2007) conducted a research where access time of vehicles to a fire was studied by using GIS tools. Akay and Kılıç (2015) used GIS tools to evaluate the efficiency of current firefighting teams considering potential forest fires.

In this study, it was aimed to evaluate not only the locations of current firefighting teams but also investigate best possible locations of firefighting teams using "New Service Area" tool in ArcGIS program. The study was implemented in Mustafakemalpaşa province of Bursa in north-west of Turkey. 


\section{MATERIAL AND METHODS}

\subsection{Study area}

Three Forestry Enterprise Chiefs (FECs) of Paşalar, Sarnıç and Turfal located in the city of Bursa were selected as study area. These FECs are classified as the second degree fire sensitive areas (Keramitsoglou et al., 2004). There is currently one firefighting team located in the north border of the study area (Figure 1).

\subsection{GIS database}

Firstly, the road network map for the study area was developed on the basis of topographic maps with 1:2500 scale. In order to determine the optimum route to reach the fire area on time, the average travel time of fire truck carrying the firefighting team should be determined for each road section. The travel time can be calculated based on the length of the road and the average speed of the fire truck. The average vehicle speed varies depending on the type and condition of the road. The Table 2 indicates the average speed of fire trucks for various road types (i.e. asphalt, gravel, and forest road) at different conditions including good, average, and bad (Akay et al., 2012).

\begin{tabular}{|l|c|c|c|}
\hline \multirow{2}{*}{ Road type } & \multicolumn{3}{|c|}{ Road Conditions } \\
\cline { 2 - 4 } & Good & Average & Bad \\
\hline Asphalt & 60 & 50 & 40 \\
Gravel & 50 & 40 & 30 \\
Forest Road & 30 & 25 & 20 \\
\hline
\end{tabular}

Table 2. The average travel speed of fire trucks (km/hour)
The average travel time was computed using the following formula (Akay et al., 2012):

$$
t_{i}=\frac{l_{i}}{v_{i}} 60
$$

$t_{i}:$ travel time for road section $i$ (minutes)

$l_{i}$ : length of road section $i(\mathrm{~km})$

$v_{i}$ : average speed of fire truck for road section $i(\mathrm{~km} / \mathrm{hour})$ 60: used to convert the unit of travel time from hour to minute

\subsection{Network analysis}

The network analysis method is widely used to solve transportation problems that require systematic investigation of the optimum route (Akay et al., 2012). In this study, the links represent the road sections in the study area, and each link value represents the travel time calculated for the corresponding road section. In order to fight with forest fire effectively, a "New Service Area" method under "Network Analyst" extension of ArcGIS was applied in the study (Figure 2), considering that the firefighting teams must reach the fire area during critical response time. In the New Service Area method, which is similar to the Buffer Analysis method as a working principle, the regions remaining within a total link value (travel time) can be determined by using a specified service point on the network system.

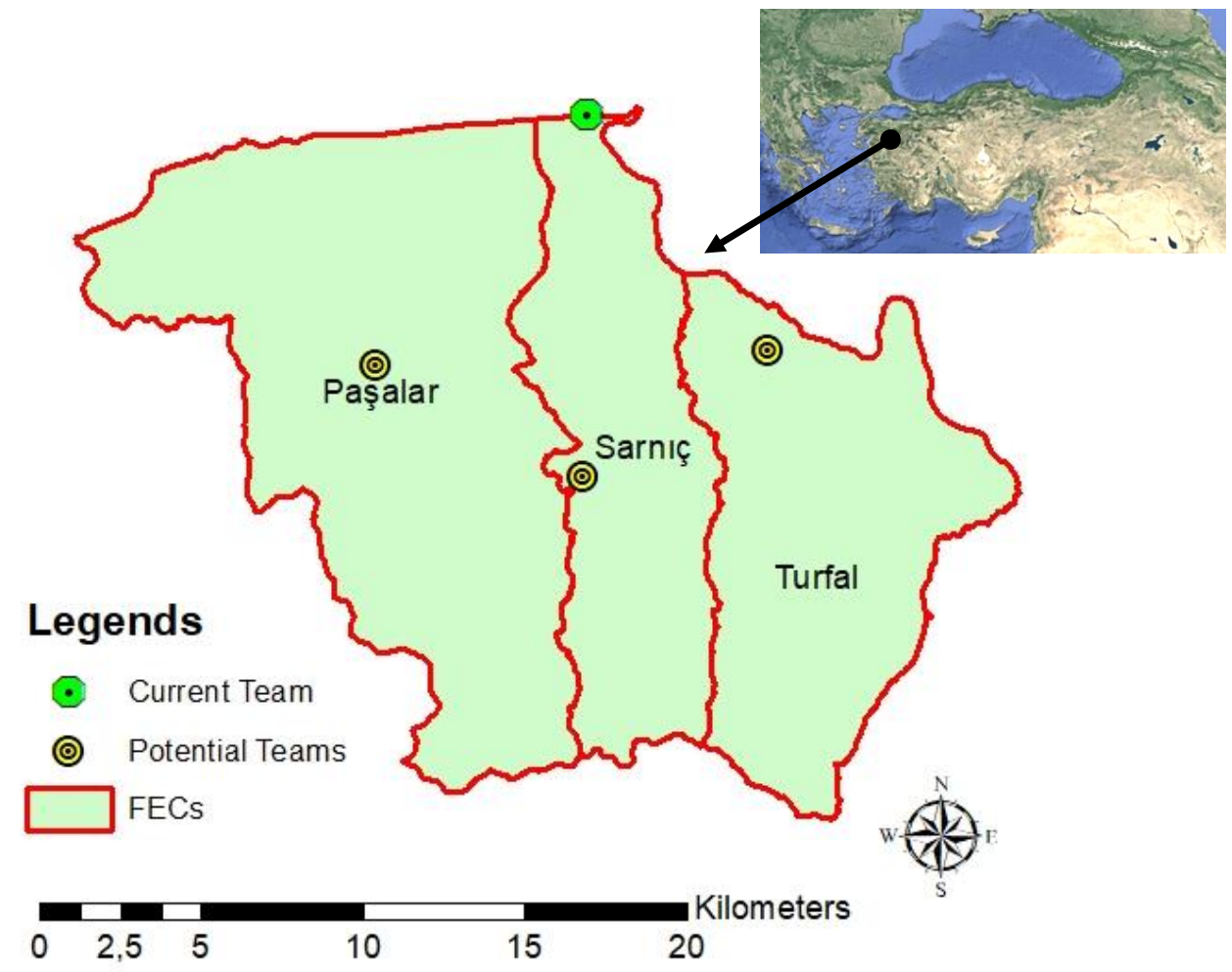

Figure 1. Current and potential firefighting teams in the study area 


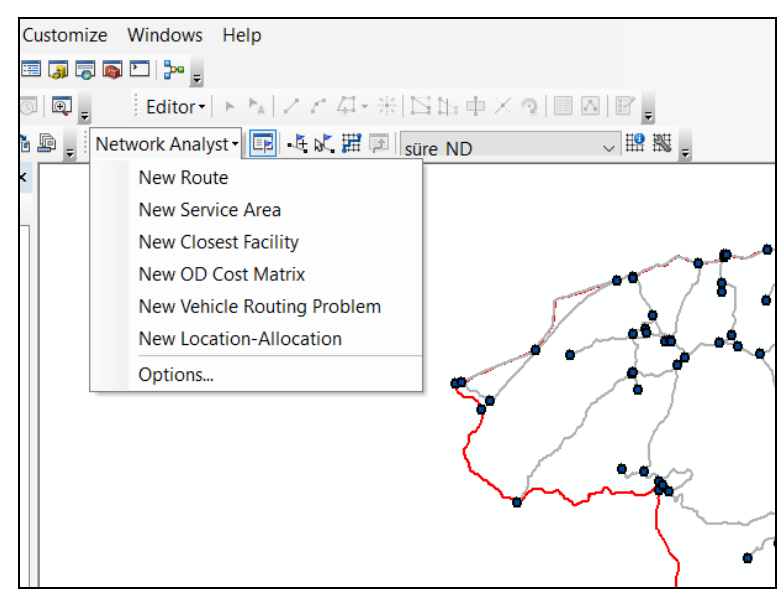

Figure 2. The methods under Network Analyst

In the development of the landuse types map, stand type maps of 2017 with 1:25000 scale, obtained from the forest management plans of the Forest Enterprise Directorate, were used. "Reclassify" method was applied and a new data layer showing the forest areas in the study area was produced.

The UTM (Universal Transverse Mercator) coordinates of the current firefighting team in the study area were recorded in the ArcGIS program. The locations of three potential firefighting teams were then evaluated by network analysis.

In this study, with the help of "New Service Area" method, the forest areas that can be reached within the critical response time were determined based on the locations of both the current team and three potential teams. In the study area, "New Service Area" method was applied considering the critical response times of 30 minutes because the forested areas in the region was sensitive to forest fires at the second degree.

\section{RESULTS AND DISCUSSION}

\subsection{Road network and landuse type}

Results indicated that total length of the road network was $525.02 \mathrm{~km}$ (Figure 3). Majority of the road section in the study area was classified as forest road $(70.83 \%)$, followed by asphalt $\operatorname{road}(17.51 \%)$, and gravel road $(11.67 \%)$.

A total of 10 different land use classes were identified in the study area according to the landuse types map developed for the study area (Table 3, Figure 4). The landuse type with the largest area was found to be forest lands $(59.76 \%)$ followed by agricultural areas $(31.32 \%)$. The results showed that the total area of forest land was 21410 ha (Figure 5).

\begin{tabular}{|l|c|}
\hline Landuse Types & Area (\%) \\
\hline Forest Lands & 59.76 \\
Agriculture & 31.32 \\
Rangeland & 3.58 \\
Open land & 1.79 \\
Settlement & 1.62 \\
Sand & 0.77 \\
Industry & 0.43 \\
Water & 0.40 \\
Mine & 0.19 \\
Depots & 0.14 \\
\hline
\end{tabular}

Table 3. Areal distribution of landuse types

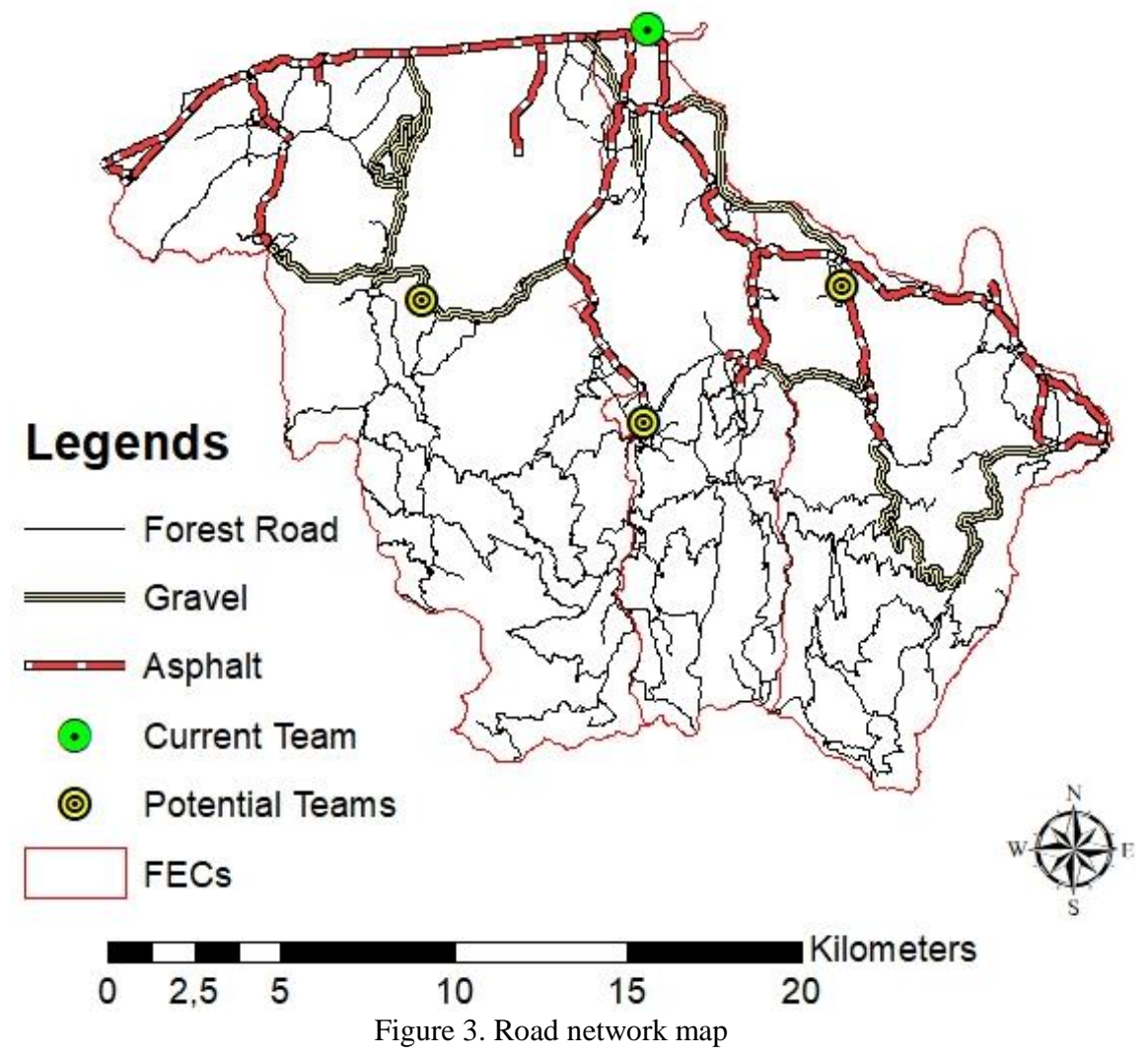

This contribution has been peer-reviewed. 


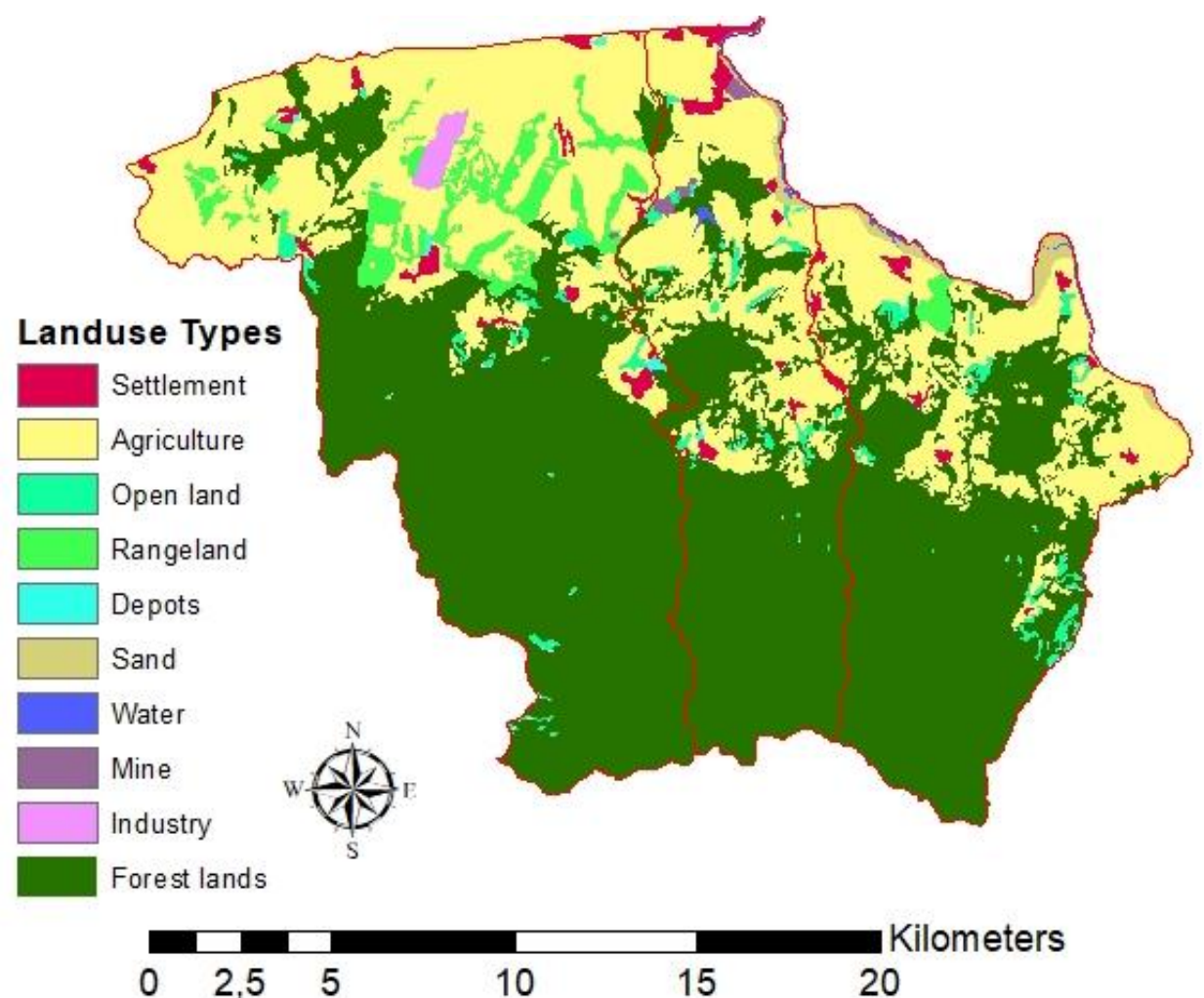

Figure 4 . The landuse types in the study area
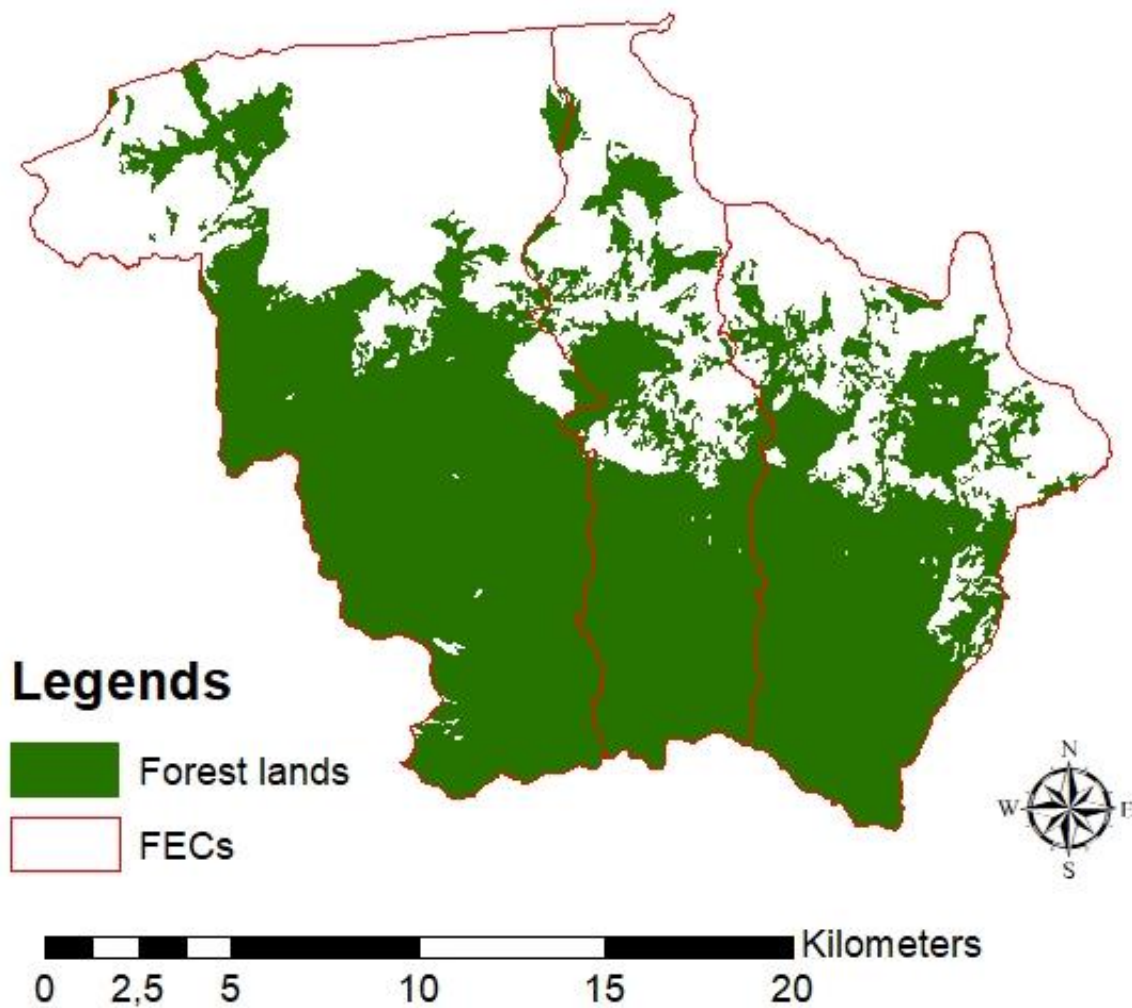

Figure 5. The map of the forest land in the study area 


\subsection{Assessment of firefighting teams}

New Service Area method was used to determine the areas that can be reached by current response teams within a critical response time. In GIS analysis, the buffer area that can be reached by fire trucks through the road network within critical response time of 30 minutes were investigated for forest lands sensitive to fire at the second degree. It was found that $31.28 \%$ of the forest land can be reached by initial response team within a critical response time (Figure 6).
In the second stage, three potential firefighting teams were located in the study area and then New Service Area method was used again to determine the areas that can be reached by them. The results indicated that $71.55 \%$ of the forest land can be reached by initial response teams within a critical response time (Figure 7).

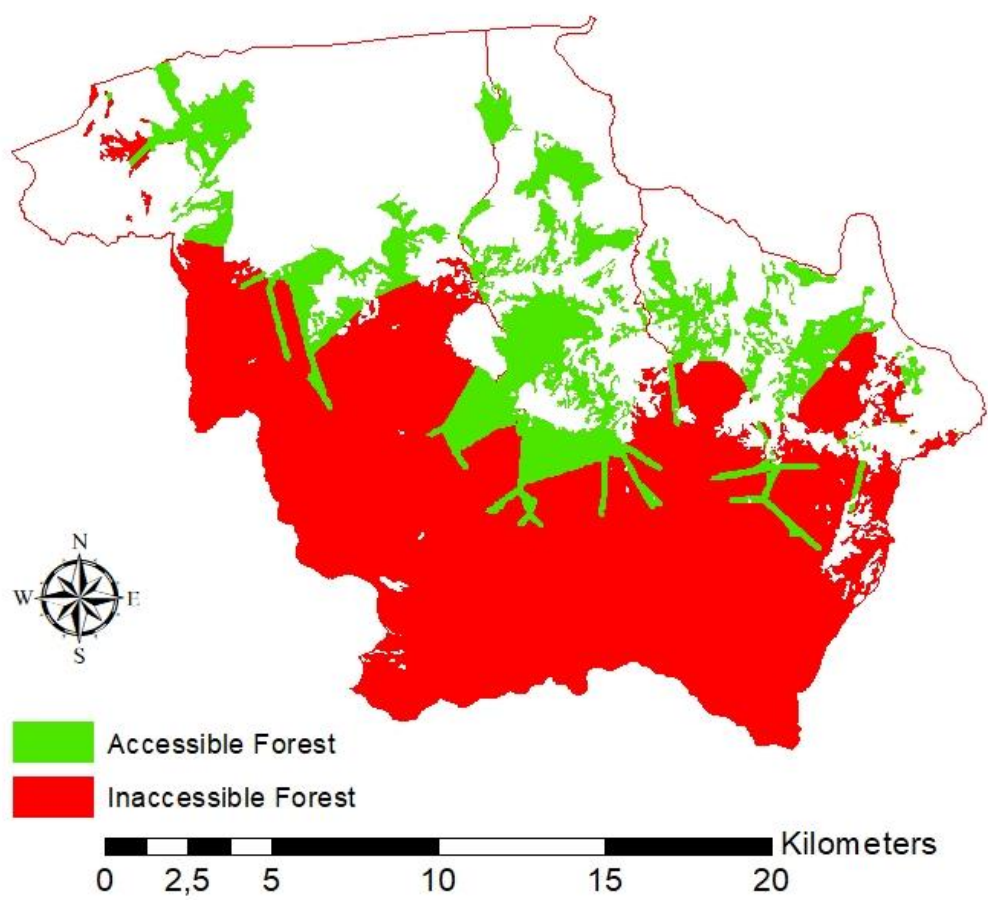

Figure 6 . The accessible forest by the current firefighting team

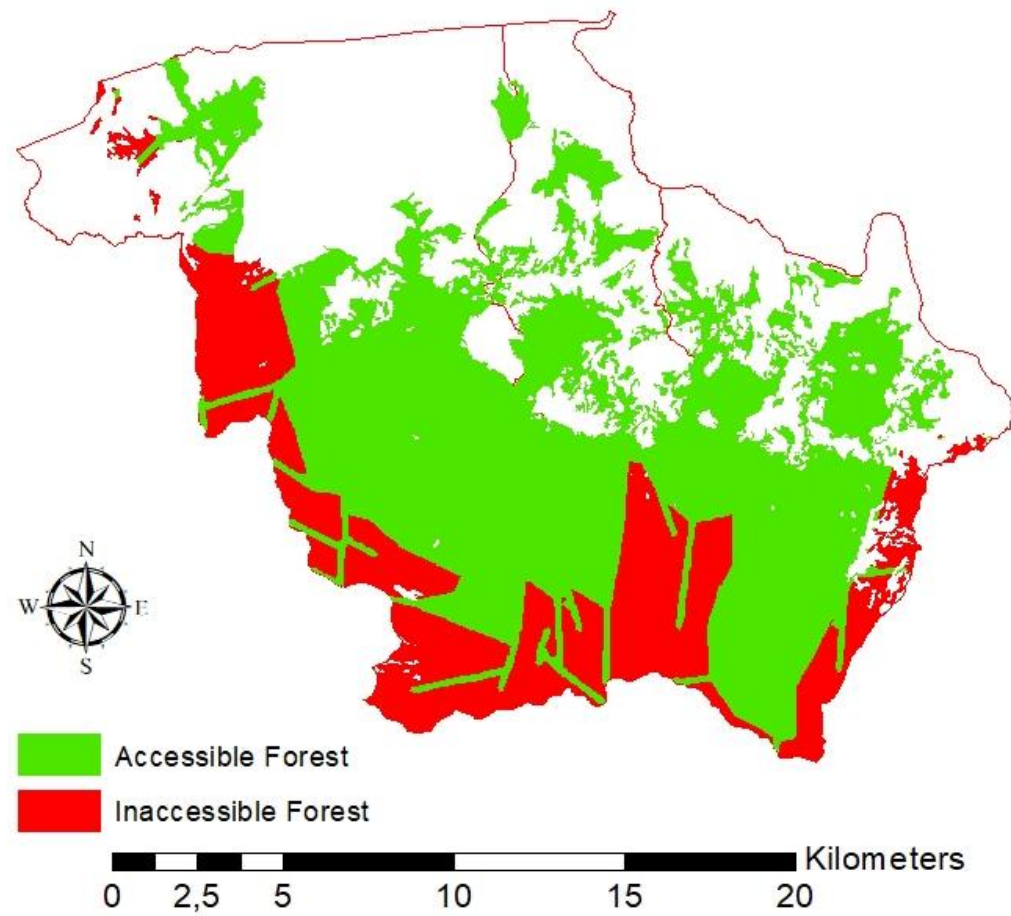

Figure 7. The accessible forest by adding the new firefighting teams 


\section{CONCLUSIONS}

The results indicated that $68.72 \%$ of the forested areas could not be reached within the critical response time by considering only current firefighting team. When including three more firefighting teams in the study area, it was found that inaccessible areas decreased to $28.15 \%$ in the study area. Therefore, the results suggested that additional firefighting teams are necessary in the region. Besides, new roads should be built or existing roads should be improved considering higher design speed. The results also revealed that a GIS-based systems can be effectively used to assist fire managers in management of the forest fires by locating potential firefighting teams in short time and evaluating the locations of current firefighting teams.

\section{REFERENCES}

Akay, A.E., Sakar, D., 2009. Using GIS Based Decision Supporting System in Determining Optimum Path that Provides the Transportation to Fire Zone at the Shortest Time. The Camber of Turkish Engineers and Architectures. The Congress of Geographic Information Systems. 02-06 November. Izmir, Turkey.

Akay, A.E., Zengin, M., Köse, O., Yenilmez, N., 2011. Evaluating Locations of Forest Fire Fighting Teams by Using GIS Techniques. VI. International Symposium on Ecology and Environmental Problems, 17-20 November, Antalya, Turkey. pp. 114

Akay, A.E., Wing, G.M., Sivrikaya, F., Sakar, D., 2012. A GISbased decision support system for determining the shortest and safest route to forest fires: a case study in Mediterranean Region of Turkey. Environmental Monitoring and Assessment. 184(3), pp. 1391-1407.

Akay, A.E., Kılıç, H.E., 2015. Providing Engineering Solutions to Forest Fire Access Problems Using Network Analysis Method. International Conference on Engineering and Natural Sciences (ICENS) 2015. 15-19 May. Skopje (Üsküp), Macedonia.

Bilici, E., 2009. A Study on the Integration of Firebreaks and Fireline with Forest Roads Networks and It's Planning and Construction (A Case Study of Gallipoly National Park)
Istanbul University. Faculty of Forestry Journal Series: A, 59(2), pp. 86-102.

Bonazountas, M., Kallidromitou, D., Kassomenos, P., Passas, N., 2007. A decision support system for managing forest fire casualties. Journal of Environmental Management, 84(4), pp. 412-418.

Dimopoulou, M., Giannikos, I., 2004. Towards an integrated framework for forest fire control. Eur. J. Oper. Res., 152, pp. 476-486.

Eker, Ö., Abdurrahmanoğlu, D.M., 2018. An Analysis on the Expenses of Combating Forest Fires: Case of Kahramanmaraş Regional Directorate of Forestry. Turkish Journal of Forest Science, 2(1), pp. 34-48.

GDF, 2013. Forest Fires Combat Assessment Meeting, General Directorate of Forestry, Ankara, Turkey.

Karabulut M., Karakoç A., Gürbüz M., Kızılelma Y., 2013. Determination of Forest Fire Risk Areas Using Geographical Information Systems in Başkonuş Mountain (Kahramanmaraş). The Journal of International Social Research, 6(24), pp. 171179.

Keramitsoglou, I., Kiranoudis, C.T., Sarimveis, H., Sifakis, N., 2004. A multidisciplinary decision support system for forest fire crisis management. Environmental Management, 33(2), pp. 212-225.

Kucuk, O., Unal, S., 2005. Determination of fire sensitivity degree: A case study in Tasköprü State Forest Enterprise. Kafkas University. Faculty of Forestry Journal, 6(1-2), pp. 2834.

Varol T., Özel H., B., Macaroğlu K., 2010. The Use Facilities of Network Analysis in the Forest Fires (Yenihan Forest Range District Case Study), III. National Blakcsea Forestry Congress, 20-22 May, pp: 1262-1269.

Revised August 2018 